\title{
THE GENERAL ELECTION OF 1859 IN THE CITIES OF YORKSHIRE.
}

\author{
A STUDY OF POLITICAL BEHAVIOUR
}

UNDER THE IMPACT OF THE REFORM AGITATION ${ }^{1}$

A study of parliamentary elections in a certain area must be preceded by the attempt to describe the character of the electorate. This is the more necessary as it is often little recognised to what a large extent the size and composition of the new electorate created by the $£$ io franchise varied from borough to borough. This was due to some extent to the strength of local registration societies and the different interpretation which the revising barristers gave to the term ratepayer, but its main cause was the character of the housing in the constituencies. Land values, custom and, of course, the wage structure of the community determined the quality and standard of building and in consequence rent and rates. ${ }^{2}$ While the urban middle classes were probably everywhere in possession of the vote the above mentioned factors clearly determine the proportion of the working-class who enjoyed the franchise. It seems useful therefore to compare the Yorkshire figures with those for other parts of the country. To do this it is best to disregard York and Hull with their large number of freemen voters and to concentrate on the newly enfranchised boroughs.

The electorates in the five new boroughs were all of a fair size; the smallest, Halifax, had I,49I electors and Sheffield over 7,000. Yet with the exception of the latter, where as the result of the many skilled workmen and small masters we expect to find a large democratic electorate, the proportion of voters, whether measured in terms of inhabitants or houses, is almost inversely related to the size of the town. In 1859 Leeds had 3.1 voters per 100 population and 15.0 per Ioo inhabited houses, while the figures for Huddersfield are 4.6 and

1 The constituencies chosen for this comparative study are: Bradford, Halifax, Huddersfield, Hull, Leeds, Sheffield and York.

2 A detailed discussion of this can be found in the minutes of proceedings of the House of Lords Select Committee on the Elective Franchise which was set up in 1859 and reported in 1860 . BPP 1860 , vol. XII. 
26.6 respectively. Taken as a whole the new Yorkshire constituencies show as many voters per Ioo of population and houses as Lancashire boroughs of equal size, and more than the Midland cities. On the other hand, these figures are far below those for the new London constituencies. ${ }^{1}$ In the latter, i.e. Finsbury, Marylebone, Tower Hamlets and Lambeth the electorate practically doubled between 1837-38 and 1856-57 while in the five Yorkshire boroughs it grew only by $43 \%$. Here, too, further differences can be noted. In Huddersfield houses were built at the rate of $2.7 \%$ per annum between $183 \mathrm{I}$ and $186 \mathrm{x}$ while the electorate grew between 1837 and 1857 at an annual rate of $4.5 \%$. In Leeds on the other hand, the number of houses increased by $2.3 \%$ annually but the number of voters by $0.5 \%$ only. $^{2}$

A comparatively small electorate means generally a small number of working-class voters and the I 865 returns of working-class voters in English and Welsh boroughs bear this out. ${ }^{3}$ There is little doubt that enumerations which excluded foremen and shopkeepers from the working class underestimate the actual size of the working-class electorate but the figures nevertheless allow for interesting comparisons to be made. Sheffield, with over $25 \%$ working class voters is well ahead here; in Huddersfield, one voter in eight belongs to the working class while Leeds, with a working class electorate of $7.2 \%$ is right at the bottom of the long list of boroughs arranged according to the strength of the enfranchised working class.

Neither a large electorate nor a numerous body of working class voters is a guarantee of democratic election procedure in the sense that they exclude corruption or pressure group influence. ${ }^{4}$ The

1 Electors as Percentage of Population and of Houses rated to the Poor.*

s new Yorkshire Boroughs

7 new Lancashire Boroughs

4 new Midland Boroughs

$\begin{array}{cc}\% \text { of Population } a & \% \text { of Houses } b \\ 3.7 & 20.0 \\ 3.3 & 17.8 \\ 2.6 & 12.5\end{array}$

* From Parliamentary Returns.

a Population figures projected to 1859 from I $85 \mathrm{I}$ Census figures, taking $184 \mathrm{I}-\mathrm{SI}$ rate of population growth.

$b$ Houses according to 1856 returns.

2 Bradford and Sheffield show a more even rate, voters growing as fast as houses. Statistics for Halifax are difficult to interpret; no accurate figures for the number of houses within the boundaries of the Parliamentary Borough in 1832 seem to exist.

3 BPP I 866, LVII, (170).

4 If election petitions may be used as criteria of electoral purity we may conclude that the Yorkshire cities - Hull, whose corruption is notorious, apart - were rather pure, only one member (W.R.C. Stansfield of Huddersfield) had ever been unseated. For figures of election petitions, I832-I 853 see The Spectator of Jan. 7, 1854, cited Newmarch, Journal of the Royal Society, 1859, pp. 226-229. 
discussion on the working of the franchise and on franchise reform is full of complaints of farcical elections, such as those in the large metropolitan boroughs and the practical disfranchisement of middle class voters in boroughs with a popular electorate. ${ }^{1}$ Yet a knowledge of the social character of the electorate is essential for the understanding of the electoral process and of the outcome of the elections here studied. ${ }^{2}$

\section{PRE-ELECTION ACTIVITIES AND THEIR}

\section{BEARING ON THE ELECTION}

We are today accustomed to regard parliamentary elections as mere milestones in the political battle between two or three major parties which is waged daily and on a national scale, while we liken the political system of the mid-Victorian era to a broad and gently flowing stream, changing its course slowly, disturbed by sudden squalls and by many small ripples of the waves, local in character and soon absorbed in the general current. This picture is the result of a perspective which is centered on the happenings in Parliament and on the expression of public opinion through the national press and the intellectual elite. It is true that political life in the boroughs between election times was comparatively quiet, yet we can clearly observe the activities of local political organizations and the attempts to mould political opinion through the medium of the local press and public meetings. The period since the first Reform Act had witnessed a steady sequence of general elections, not to count frequent byelections. Unlike the smaller boroughs in Yorkshire where only 42 out of 77 possible general election contests had taken place since I 832 , the cities saw only three uncontested elections. The election of 1857 is of special importance in this context. It had been one of defeat and disappointment for the radical cause both in the country at large and in Yorkshire. In Manchester Bright and Gibson were thrown out by Whigs and entrepreneurs who desired more orthodox and "respectable" representatives. ${ }^{3}$ Fox and Miall were equally defeated and Cobden lost the election in Huddersfield, an event which was to have some bearing on the 1859 election there. In Leeds, Forster, the popular candidate, representing the advanced section of the Liberal party was defeated at nomination by a combination of whiggism and dissent embodied in the Baines family and John

1 Cf. House of Lords' Committee on the Elective Franchise, BPP I 860, vol. XII.

2 See below pp. $254-256$.

${ }^{3}$ Cf. J. Morley, Life of Cobden, p. 663 and F. Richards: John Bright and Manchester, 1859 . 
Remington Mills was adopted as second Liberal candidate, but defeated at the polls. ${ }^{1}$ Gradually the reformers regained strength. Bright, barely recovered from his serious breakdown which had incapacitated him since 18,6 , was elected unopposed in Birmingham in I 858 . On the $27^{\text {th }}$ of October he made his first public speech there and inaugurated a campaign for franchise reform which saw crowded meetings in Manchester, Glasgow and Edinburgh and culminated in a meeting in St. George's Hall, Bradford, on the 19th of January, at which he outlined the provisions of his new reform bill. His speeches sought to give a fillip to popular agitation and demonstration. Suggesting to his Birmingham audience that reformers should draw up and present to Parliament a bill embodying their proposals he asked "... why should we not with all the unanimity of which we are capable, by public meetings, by petitions, and, when the proper time comes by presenting ourselves at the polling booths, do everything in our power to pass that measure into Law?"2

The Bradford meeting itself was followed by a "Reform Conference" convened by the Bradford Liberal Registration Society at which Bright was present. Its outcome was the formation of a West Riding Reform Association "for the purpose of carrying through the comming session of Parliament a real Reform Bill" ${ }^{3}$ Bradford was not the only Yorkshire city to hold such a meeting; Hull had already held one on the $27^{\text {th }}$ of December 1858 , Sheffield followed suit on the 13 th of January and Halifax was to hold one at the end of the month. ${ }^{4}$ The meetings were usually convened by the Mayor, following a petition by the prescribed number of citizens. The more radical of the reformers were clearly behind this and those Conservatives who were present and dared to speak were given anything but a sympathetic hearing. The Halifax meeting was arranged by the Halifax Household Suffrage and Ballot Association, altogether an active body. On the last day of February Disraeli outlined the government's reform proposals to the Commons and on the $3 \mathrm{rd}$ of March the Association held a meeting to 'discuss' the government measure and to petition the House of

1 Cf. A Letter to Edward Baines on his treatment of W. E. Forster and the Leeds Electors (1857). See also below p. 239, n. I.

2 J. E. T. Rogers (Ed.) The Public Speeches of John Bright, vol. II, p. 29.

3 The first enthusiasm soon waned, however, and the unanimity was more apparent than real. A meeting of the provisional committee held a week later resolved that the purpose of the association shall be 'the achievement' of some extensive measure of parliamentary reform' but refused to pledge itself to Bright's bill or that of any other statesman.

4 The Leeds Mercury reports during January also Reform Meetings in Doncaster and Pudsey. 
Commons to reject the bill. "We urge our readers to attach their names to the petition at once" wrote the Halifax Courier. Within a week more than 2,000 signatures had been collected.

The government proposals gave rise to a second series of meetings all ending in the rejection of the bill and in the demand for more radical reforms. These meetings followed a fairly regular pattern. They usually opened with a resolution condemning the government measure, protesting especially against the disenfranchisement of borough voters in respect of the counties. A second resolution urged the extension of the franchise, demanding either a rating franchise or the enfranchisement of the "industrial classes of the country". Either together with this resolution or separately, there is usually a demand for the ballot. These two were, as a rule, followed by abortive attempts on the part of some members of the audience to raise the subject of universal suffrage. The bulk of the audiences showed itself generally hostile to such proposals. This was not necessarily due to a lack of sympathy by those present, but the unanimity which prevailed even for such radical proposals as household suffrage and the ballot was of a recent and precarious creation, to maintain it for a future election seemed urgent. Extreme demands which would make people aware of the chasm which divided the Liberal camp were clearly dangerous and had best be suppressed. Liberal papers urged their readers to renounce extremists' demands for the sake of "unity". "Is it not worth while of the most ardent reformers to give up some of their demands in order to obtain even a portion of what they require?" wrote the York Herald. ${ }^{1}$ Such sentiments were to be expressed increasingly as the prospects of a General Election became more certain. The Reform Bill was defeated at the second reading on March 3 I st., and after some wavering the government announced that it proposed to dissolve. By the beginning of April the preparations for the coming electoral struggle were well on the way. Committees met, intrigues were started, the local papers exhorted their readers to support $X$ and began to villify $Y$. Members - and candidates where these had already been selected appeared in their constituencies. James Clay, perhaps best known as a writer on Whist but a popular M.P. for Hull for $2 \mathrm{I}$ years and Mr. Harvey Lewis, the "prospective Liberal candidate" arrived in Hull on April 8th and were conducted by a large procession to the "Cross Keys" from a window of which they addressed the crowds.

1 As the local press forms the main source for this study of the election no references for individual quotations will be given. Although local papers follow political lines there was little biased reporting. The fact that most towns had two or more journals (of different views) made it possible to gain a fairly balanced view. 
THE CHARACTER OF THE CONTEST IN YORKSHIRE

At this point, before we, so to speak, enter on the hustings, it seems necessary to delineate the general character of the contest. Except in Sheffield where the position of Hadfield and Roebuck was unassailable, contests were begun in all constituencies and except in Halifax, where the conservative candidate withdrew before nomination, they were carried to a poll. Fourteen candidates contested the remaining nine seats. The result seemed to leave the character of the representation unchanged. ${ }^{1}$ The seven cities were represented by three Conservatives, one Independent Radical and ten Liberals of whom five were pledged to support electoral reform along the lines advocated by Bright. There had been four Conservatives among the representatives in the old House but one, Wickham of Bradford, had steadily moved towards the Liberal camp since he had been returned for the first time in 18 \&2, and though returned jointly with Thompson unopposed in 1857 , he was now no longer acceptable to the Tories who put a candidate of their own into the field. The sitting members were all reelected with the exception of Edward Ackroyd, a Whig, who was defeated by a radical candidate. The Liberals everywhere headed the poll and their second and more radical candidate was in most cases defeated by a combination of plumping and splitting which led to the return of two candidates of different persuasions. All this seems to repeat familiar features of previous elections; perhaps The Times was right when it wrote of the election (I gth April): "An English borough with its 1,200 or 1,500 electors is always prepared for a fight but the rivalry except in remarkable instances finds its ailments and its expression in the politics of the place itself... Each may have a cry and the best cry may be a certain advantage but in the main and with the bulk of the community it is simply Blue against Yellow". We shall have to look at the selection procedure and the men who stood for election and not the M.P.'s alone to find an answer to this question. To do this we have to disentangle the part which patronage, prestige and principle play in the events which lead to the adoption of a candidate.

\section{THE CANDIDATES AND THEIR SELECTION}

The nineteen candidates who sought election in the seven constitu-

1 The result for the whole of the country showed a gain by the Conservatives of some 30 seats. But although Grenville boasted that the election had "elicited the completely Conservative spirit of the country", the government was not strong enough to withstand the pressure of a united opposition. They were defeated by 13 votes at the beginning of June and resigned. 
encies were of a similar type as a great number of their constituents. ${ }^{1}$ All but two were members of the great middle class, richer no doubt than the average but men who for a great part of their lives at least had followed careers in commerce, industry and the professions. They were mostly in their fifties at the time of this election and as only one had entered Parliament before I 847, they were men who first sought election when in middle life. The Dictionary of National Biography contains entries for nine of them and only five can claim to have made a mark as politicians but considering the large number of those who pass through the House of Commons on their way to oblivion, this is really a high figure. On the road to political success the comparative lack of education which distinguishes them must have been a handicap. Roebuck had clearly such men in mind when at the nomination meeting in Sheffield he commented on the lack of training and the higher age of the middle class legislator compared with his aristocratic colleague and urged "the middle class of this country to prepare their children by study for the business of government". Only three went to a Public School and four to Oxford or Cambridge. In addition, two had attended London University but the bulk had only the experience of a Grammar School or a non-conformist Academy to the age of seventeen. Only five were non-conformists. Considering the strength of dissent in Yorkshire and especially in the West Riding, the figure may seem low, yet their candidature and their success (all five were elected) is a remarkable phenomenon if seen in the context of the time. Until 1847 and the all-out drive of Edward Miall's Dissenters' Parliamentary Committee there had usually not been more than a handful of nonconformists in the whole of the House of Commons. These merchants, bankers, ironmasters and mill-owners who together with two lawyers, two landowners and two freelance writers cum rentiers presented themselves as candidates thus resembled the upper crust of local

1 i.e., in Bradford: A. Harris ${ }^{a}$, H. W. Wickham, T. Salt.

in Halifax: Sir C. Wood, J. Stansfield, S. Waterhouse ${ }^{b}$.

in Huddersfield: E. Ackroyd ${ }^{a}$, E. A. Leatham.

in Hull: J. Clay, J. H. Lewis, J. Hoare.

in Leeds: E. Baines, G. S. Beecroft, W. E. Forster ${ }^{a}$.

in Sheffield: G. Hackfield, J. A. Roebuck.

in York: J. P. Brown-Westhead, H. A. Layard ${ }^{a}$, J. G. Smyth.

a defeated at the polls.

$b$ did not go to the poll.

Of the defeated candidates four soon found seats elsewhere. 
society. ${ }^{1}$ Men like them manned the committees of local political associations and were then and for a considerable time to come, influential in the selection of candidates for political office. Did they prefer local men? No clear cut answer to this question can be given. Only six can definitely be described as local men, but on the other hand, only five as "carpet baggers" pure and simple. The rest are men of the county who contested neighbouring constituencies or boroughs with which they were connected through strong family ties. Both Hadfield and Stansfield were born in the towns which they contested, Edward Ackroyd, a Halifax millowner sat for Huddersfield, W. E. Forster whose textile works were in Burley near Bradford contested Leeds. ${ }^{2}$

${ }^{1}$ One of them, John Harvey Lewis, who contested Hull, is a particularly picturesque character. Born in 1812 , the eldest son of an Irish landowner, he studied at Trinity College, Dublin, was called to the Irish Bar and seems to have practised law from 1838 to 1850 . He was High Sheriff of Kildare in 1857 , became a shipowner, and founder and Chairman of the Galway-America Line. In 1857 he contested Bodmin as a $4^{\text {th }}$ candidate appearing rather suddenly on the scene. The West Britain described him as "a man of large fortune and untrammelled by any party or pledge" but he himself claimed to be a supporter of Lord Palmerston. His election address was largely concerned with religious and social questions. He was, he said "a staunch supporter of the Protestant religion" and he hoped that the answer of the electors "would be one of the most decided noes to Puseyism ever given". Yet financial considerations also weighed on his mind. "Some considerable portion of what he possessed in this world" he declared "was invested in the neighbourhood of Bodmin" and according to his supporter, Mr. Stripp, he had invested in mines and had been the instrument of sending no less than $\mathfrak{f}_{4000}$ there. He was heavily defeated there and subsequently twice at Hull but finally succeeded in Marylebone in I 861 .

Candidates in the Seven Constituencies

\begin{tabular}{|c|c|c|c|c|c|c|}
\hline Occupation: & Total & Elected & Defeated & Conserv. & $\begin{array}{l}\text { Moderate } \\
\text { Lib. }\end{array}$ & Radical \\
\hline Landowning & 2 & 2 & - & - & - & - \\
\hline Professional & 3 & 2 & I & - & - & 3 \\
\hline Merchant, Banker etc. & 6 & 4 & 2 & 2 & 2 & 2 \\
\hline Manufacturer & 6 & 4 &, 2 & I & 2 & 3 \\
\hline $\begin{array}{l}\text { Rentier } \\
\text { Education: }\end{array}$ & 2 & $\mathrm{I}$ & $\mathbf{I}$ & I & - & I \\
\hline Grammar School only & II & 7 & 4 & 2 & 4 & 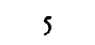 \\
\hline 'Oxbridge' & 4 & 4 & - & 2 & $\mathrm{I}$ & I \\
\hline Other University & 3 & 2 & $\mathbf{I}$ & - & - & 3 \\
\hline Unknown & I & - & I & I & - & - \\
\hline \multicolumn{7}{|l|}{ Religion: } \\
\hline Church of England & I3 & 8 & 5 & 5 & 4 & 4 \\
\hline Dissent & 5 & 5 & - & - & I & 4 \\
\hline Uncertain & 1 & - & I & - & - & I \\
\hline \multicolumn{7}{|l|}{ Connection witb Constituency: } \\
\hline Local Men & 6 & 4 & 2 & 3 & 2 & I \\
\hline Men of the County or local tie & es 8 & 6 & 2 & I & 3 & 4 \\
\hline Carpetbagger & $s$ & 3 & 2 & I & - & 4 \\
\hline Total & I9 & 13 & 6 & 5 & $s$ & 9 \\
\hline
\end{tabular}


Yet the local appeal was strong and its connection especially with Conservative or Conservative supported candidates was marked: three of their five candidates were local men and another - the sitting member for York - the eldest son of a Yorkshire Landowner and a Deputy Lieutenant for the West Riding. "The names of Waterhouse" (the "independent" candidate who came out with strong Conservative support) "and Halifax have long been honourably connected together" wrote the Halifax Courier "and it is homely as we believe it will be a triumph cry 'Waterhouse for Halifax'". Local sentiment as much as a cautious attitude towards reform must have motivated the citizen of Leeds who in defiance of the decision by the bulk of the Liberal party proposed to bring out Sir Peter Fairbairn, the Mayor, instead of W. E. Forster the candidate of the radical section. Placards with Fairbairn's name appeared on the eve of the adoption meeting and the Mercury carried an advertisement which ran: "Liberal electors, attend the meeting this evening and vote for Sir Peter Fairbairn and Edward Baines, our townsmen". However, Fairbairn fared badly at the meeting largely, one imagines, due to the reluctance of many voters to repeat the split which had occurred in 1857 over Forster's nomination. ${ }^{1}$ The supporters of the Mayor made a gallant attempt, stressing both his local standing as well as his moderate political views. With regard to the franchise he would have probably gone as far as Baines, the candidate of the moderate Liberals, but unlike him he was opposed to the ballot. "Then" said a man interrupting the speech of his seconder "he won't do". When it came to the vote there were at first 20-30 hands raised but seeing their hopeless position, all but a handful withdrew.

Bradford, Halifax and York were confronted with similar problems although in each case the decision was complicated by the fact that the sitting members sought re-election. In each the advanced section of the Liberal party attempted to nominate at least one candidate who, like Forster, would be in favour of Household suffrage. The position in Halifax was comparatively simple. The town was already represented by two Liberals, Sir Charles Wood and Frank Crossley, the one an outright Whig, the other inclining more and more towards radical policies. Crossley however accepted nomination for the West Riding and Halifax Liberals had to fill his place. They had before them John Remington Mills, twice defeated at Leeds and James Stansfield, both

1 In 1857 there had been a volte face in the last minute. After an original meeting had decided on M. T. Baines and W. E. Forster as joint candidates the moderate wing withdrew their support and eventually adopted J. R. Mills as second candidate. See: A Letter to Edward Baines on his treatment of W. E. Forster and the Leeds Electors, Leeds (1857). 
invited by the Liberal Registration Society. Stansfield was clearly the choice of the Liberal electors present at the meeting; only a few hands were raised in favour of Mills. The point at issue between them was the extent of the proposed franchise reform; Stansfield advocated household suffrage while Mills would go no further than a $£$ s rating. As there was no poll, we have no means of knowing whether Wood or Stansfield was the popular candidate, but the latter was certainly the candidate of the "Household Suffrage and Ballot Association" who met a few days after his adoption to express their support. They passed the following motion:

"That this meeting believes it is advisable at the present juncture of parties to use its utmost influence to secure the return of J. Stansfield jnr., he being a candidate fully representing the views and objects of the association and also to support Sir Charles Wood but requesting that he will give his adhesion to the Reform Bill intended to be brought in by Lord John Russell".

The latter, while in favour of "a measure of sound and constitutional reform suited to the present state of intelligence and independence of the people of England" 1 would certainly accept no dictation from his constituents. "The form in which the opposition (to the Conservative Reform Bill) should be conducted will be best determined on by persons of practical experience in Parliament" he wrote to the secretary of the association.

Bradford had in T. P. Thompson a representative whose radical sentiment was not in doubt but who, at the same time, was getting old and somewhat crochety. Leading Liberals desired to replace him by someone more attentive to local interests. He sat together with H. W. Wickham, a local ironmaster, who, although elected as a Liberal Conservative, had leant increasingly towards the moderate Liberal point of view. With these two candidates willing to seek re-election the borough entered the impending contest. The town, thought the Bradford Review, the more radical of the two (Liberal) Bradford papers, ought to be able to return "two thorough-going Liberals" provided the party was united. Yet in view of the Liberal support which Wickham had enjoyed in the past his candidature had to be considered. Hence, the paper added, his vote on the second reading of the Reform Bill would be a touchstone of his attitude. "Should he vote for the government bill... this will at once decide the point that he must not go again for Bradford". Wickham took the hint (if it needed taking) and voted with the opposition, thus paving the way

1 From his election address. 
for Liberal toleration of his candidature. The Conservatives, on the other hand, withdrew their support. "A good man and true will be brought forward to represent all the interests of all the moderate men" read a Conservative placard which appeared while the Liberals met in private to select their candidate. In the light of this the latter were obviously well advised to chose one candidate only and to select a man who would have as broad a following as possible. Hence Edward Miall, who seemed to have been originally the most favoured of the four or five candidates whose names were before the first selection meeting, was persuaded to withdraw in favour of Titus Salt who, in addition to being a non-conformist and a supporter of radical measures, was a local man. ${ }^{1}$

York shows most clearly the conflict between local interests seeking to return local men and the attempt by the Liberal party to strengthen their representation even if that meant introducing an outsider. Why this conflict had to arise, why it was impossible to find "a man of standing and position, known and respected in the country and if possible a resident in this county as every exertion should be made to return men who will oppose everything calculated to lead to centralization" as the (Liberal) York Herald had suggested, seems difficult to say now but it is likely that no local radical had sufficient standing. The choice of a radical as a second candidate was dictated here as elsewhere by the need to have a united Liberal party and to give a counterweight to Mr. John F. Brown-Westhead whose sincerity in the Liberal cause had been questioned. ${ }^{2}$ The candidature of A. H. Layard, a London radical, explorer of Niniveh and late member for Aylesbury, was therefore received as an affront to his opponents and was felt to be a risk to his friends. His colleague in the contest admitted that Layard's candidature would expose him "in many respects to a considerable loss of good feeling on the part of many" while the Lord Mayor, who contrary to tradition had entered the election fight and put himself at the head of the conservative forces to "prevent the representation of York from falling into the hands of strangers", stressed the services which Col. Smyth had rendered to the town. "An unworthy attempt was being made to drive away the last of the country gentlemen by the introduction of a total stranger into the city". The members for York ought to be gentlemen connected with the county.

1 This was important also vis a vis the followers of General Thompson. The latter, who had been thrown over rather unceremoniously had declared his willingness to stand down in favour of a local candidate provided he would be in favour of the ballot.

2 See a letter by C. E. in the York Herald of March 26 according to which Mr. Westhead "has not acted with that candour which a gentleman representing the Liberal cause and one who expects to retain the confidence of the Liberal Party should have done". 
"What would become of the assizes" asked the Mayor "if we lost the services of Col. Smyth who was a magistrate and a country gentleman; what influence (would) Mr. Layard possess in this respect and what services could he render to the city of York?"

THE ISSUES

Writing in the concluding stages of the election campaign The Economist noted and deplored the absence of election cries around which the parties could have rallied their followers. Both parties, the journal wrote, were at one in their desire to support peace abroad while in home policies their position differed only "indistinctly". Deprived of a decision on general principles the elector ought to make up his mind on the basis of the position of individual candidates and to consider their attitude to the franchise. Reading the speeches and election addresses of leading politicians it is indeed difficult to see on what grounds - and even why - the election was fought. According to Derby and Disraeli (who in his election address omitted any reference to the defeated Reform Bill) the country ought to "rally round Her Majesty's government" and allow the Conservatives to provide the stable government which only they and not the hopelessly divided Liberal Party under Lord John Russell's vaccillating leadership could give it. According to the latter, the government's action in dissolving was vexatious and unnecessary. Two thirds of the House of Commons had been in agreement of the principles of a good reform bill and only details remained to be adjusted. A Liberal government, he promised his electors, would carry out an "immediate, sound and moderate constitutional measure of reform". His vexation was echoed by the Manchester Guardian who said "The English world is too hard worked and anxious, too much occupied with... cares... to enjoy being turned upside down just for the fun of things". For Sir John Packington, First Lord of the Admiralty, on the other hand "the issue (was) simple and intelligible: on the one hand moderate reform and progressive improvement, on the other hand unsettled policy too likely to end in democratic innovation and revolutionary change". For Sir James Graham it was a question of "Reform or no Reform" but according to the Attorney General addressing his rural constituents, an extension of the Franchise was "not really and truly called for either by public voice or by public opinion". The latter's sentiments were hardly echoed in the Yorkshire manufacturing towns. Here the Conservative candidates did not attempt to defend their party's Reform Bill but on the contrary promised some extension of the 
urban rating franchise. ${ }^{1}$ The reform question certainly overshadowed any other in the contest if the reflection of the campaign in the local Press is any guidance. In this connection it was John Bright's program, especially his advocacy of the Household franchise and of the Ballot rather than Lord John Russell's proposals, let alone those of the government which agitated people's minds and became the acid test of a candidate's political opinions. ${ }^{2}$

The strength of the reform agitation had forced the older and socially weightier section of the Liberal leadership into an uneasy alliance with the "popolo minuto" who formed the leadership of the more radical wing. ${ }^{3}$ The two sides, thus harnessed together, tried to keep in step. In Leeds, Baines and Forster played down the differences which existed between them and the Mercury tried to make Forster's candidature palatable to moderate Liberals while at the same time asserting its own views which were, of course, those of Edward Baines, its proprietor and the moderate Liberal candidate. "We need", it said, "such far-going men to drag or push on those gentlemen who voluntarily would not take a single step in the direction of Reform..." and foreseeing that many Liberal candidates, despite their election promises, would not even go as far as Lord John Russell's proposals it adds that "it is important that the Liberal Leader should be supported also by (men) who, alike Mr. Forster, while theoretically going further, feel that such an extension would be a vast boon to the working classes and therefore hail it as the best practical measure". The differences between Forster, who supported Household Franchise and Baines who would not go further than a $\& 6$ rental was really greater than the "gulf" which separated him from his conservative opponent who was prepared to admit $£ 8$ householders to the vote. The conservative candidates were not unjustified in claiming the support of moderate Liberals; as far as the franchise was concerned the difference between them and their Whig opponents often amounted to only Io/- or $20 /-$ in terms of annual rent, or at the utmost 1,000 to 2,000 voters in a

1 Only E. A. Ackroyd based himself on the government bill when he declared that he would be in favour of a $£ 25$ Savings Bank franchise tather than the $£ 60$ proposed by the government.

2 The question of Church-rate repeal was one which had potentially a greater urgency but at this time it had in our constituencies with their strong non-conformist element almost ceased to be an issue. Those of the candidates who were Churchmen generally sided with E. A. Beacroft, the Conservative candidate in Leeds who declared in his election address that he wished to "accord to others the same freedom in religious matters which I claim for myself". Where there had been some equivocation in this matter the campaign forced candidates to come out squarely for repeal.

${ }^{3}$ See below. 
large borough. ${ }^{1}$ The uneasy alliance between Whigs and Radicals gave scope for these attempts -- they are evident in the cross-voting which the election produced - but it did, at the same time, give scope for the sustained attack on the "revolutionary attitude" of the more extreme of the two Liberal candidates. The campaign in York and Hull was mostly directed against the radical candidate; in Hull, Lewis, the erratic second Liberal candidate, was especially unfortunately placed. Having expressed views at his adoption in 1858 which could be interpreted as support for manhood suffrage, he was now assailed as a "revolutionary Irishman" and charged with sentiments more radical than those he now professed to hold.

On the other hand, lack of decisiveness on the reform issue led to public and newspaper pressure and forced the candidate into an unequivocal declaration of his sentiments. Harris, the Conservative candidate in Bradford had at first come out with a rather vague election address. "I dearly cherish the institutions of my country, I honour the altar, the throne and the cottage" he began and went on to affirm his support for the "enfranchisement of the intelligent and honest-hearted workingmen" as well as his liberal attitude in the church-rate question. A week later he was forced to issue a second address in which he begged to declare that he was "in favour of a $£$ Io franchise in the counties and a $£ 6$ rating in the boroughs" and that he desired "that dissenters shall be entirely relieved from any payment (of church rates) whatsoever".

It is in the Huddersfield election that we can best observe the influence of the ballot and franchise question on the electoral contest. The town had been the scene of a bitter struggle in 1857 when Cobden was defeated by a combination of Palmerstonian Liberals and Tories. The dissensions within the Liberal camp persisted until a short time before the present election when a truce was effected which was to secure the unopposed return of the sitting member at the next election. The advanced section of the Liberals, so it was expected, would give Mr. Ackroyd their support as the moderates had given it to Lord Goderich in 1852 . This truce, still manifest at the Reform Meeting at the end of March held until the adoption meeting of Ackroyd and into the first week of his leisurely electioneering. The loyalty of the advanced section however, already strained by Ackroyd's parliamentary conduct, his qualified support of Lord Derby and his opposition to Trelawny's Bill on the church-rate question was put to a

1 Any comparison of franchise proposals must take into account the differences between rental and rateable valuc. Thus a proposal to confer a $\mathfrak{f} 6$ rating franchise and an $\mathfrak{f} 8$ rental come to very much the same thing. 
further test by his refusal to support the Liberal candidates in the West Riding. ${ }^{1}$ Out of this situation began negotiations between E. A. Latham, a Wakefield banker and brother-in-law of John Bright, and some local radical leaders which resulted in Leatham's candidature. ${ }^{2}$ His victory may well have been the result of a too freely flowing beerbarrel but there can also be little doubt that general principles of political conduct, expressing the aspirations of different groups of the population acted as strong solvents in this process. Ackroyd stressed his independent support of the Derby administration, expressed general approval of Russell's scheme as well as of the optional ballot and through that appealed to the votes of both Liberals and Conservatives. He rested his claim, he said, on the support of his friends behind him who were "the leading merchants and manufacturers of Huddersfield and knew whether he was a proper person to represent them". Contrasted with this, Leatham could state that the question before the electorate was "whether the industry of England shall attain its due share in the government of England" and answer it in the affirmative by advocating household franchise and the ballot.

Being a radical candidate and being more or less a carpet bagger was largely identical. It is, so it seems, the latter rather than the former which is responsible for the springing up of minor issues, often somewhat unreal and far-fetched yet sufficiently strong to influence the conduct and possibly even the outcome of the election. Such issues could be raised more easily because of the inadequate knowledge which the electorate had of the candidate and its willingness to lend an ear to rumours which although difficult to substantiate were equally difficult to disprove. Clay as well as Layard was charged with unorthodox religious opinions; each was alleged to deviate from the norms of "right" behaviour at different ends. Against Clay it was held that he leant towards Romanism; had he not after all held a conversation with Father Trappes as late as eight years ago and had he not voted for the Maynooth grant? Layard, on the other hand, was charged

1 While this outright opposition by Ackroyd to the West Riding Liberal Registration Society was somewhat unxpected the conflict between certain sections of the Liberal leadership and the Society appears to date from 1847 when the latter was captured by non-conformist groups and came out strongly in favour of voluntaryism in education, a move strongly resented by the Whigs. Ackroyd's attitude brought about counter measures from the West Riding Committee Rooms which issued orange cards, urging Huddersfield voters to support Leatham.

2 Whether the first move in the negotiations came from Wakefield is not quite certain. On the Huddersfield side the initiative came largely from Josiah Woodhead, proprietor of the radical Huddersfield Chronicle which from the beginning of the campaign had agitated against Ackroyd. See also Huddersfield Election Petition, $1898-2692$ and 4877-5263. 
with laxity in religious matters because of his support for the Sunday opening of the Crystal Palace and the British Museum. Such issues were often raised by pressure groups rather than by individuals. In Hull the "Religious Freedom Society" sent questionnaires to three candidates to elicit their views on Church Rates, Education and Sabbath Observance. The society represented the dissenting rather than the Church point of view and their aim in obtaining the opinions of the candidates may not have been entirely disinterested. ${ }^{1}$ The answers which the three candidates gave to the last question are illuminating in the subtle differences which they reveal. Hoare declared his willingness to "oppose any measure having a tendency to desecrate or secularize the sabbath with all his heart and soul" while Clay and Lewis were prepared to leave the decision to the feeling of the community which, so they recognised, was "most decidedly in favour of the existing observance of the Sabbath".

The "Drink Question" provided another field for operation of pressure groups. The Brewers as well as Temperance Leaguers exerted pressure on the candidates. The former found little or no distinction between the candidates of different persuasions but the latter came out strongly in Halifax where the radical candidate was a brewer. At a meeting in favour of the "Permissive Bill" voters were urged not to support Stansfield. Although he agreed in many ways with him, a speaker said, "if a man possessed 999 good qualities, if he were a brewer that fact overruled them all". The bulk of the meeting however thought otherwise and supported a resolution "deeply regretting the fact that James Stansfield is engaged in the liquor trade and while strongly and earnestly protesting against such traffic, is nevertheless of the judgement that in the present state it would be impolitic and unwise to make this the sole test of his fitness to represent the borough of Halifax."

The services which the sitting member had rendered to his constituency were, of course, emphasized by the candidates and by the electorate. Beecroft could point to the fact "that he was no longer an untried man" and one of the many arguments adduced in favour of Col. Smyth in York related to his alleged services in preventing the removal of the assizes from the town. The borough of Hull, it appears, was most in need of the services of an attentive member. As a port, with shipyards building vessels for the Navy and engaged, at the time of the election, in a struggle with the Dock Company which sought to strengthen its monopolistic hold on the trade of the town through a

1 According to the Conservative Hull Packet they were "an association for the spread of political radicalism". 
new charter, this need is understandable. These services, we are told by the Conservative Hull Packet writing after polling day, had been performed by Clay who in consequence had received Conservative votes at the election, but full of excitement over the victory of the Conservative candidate they had visions of turning him out the next time. "If Mr. Hoare (the successful Conservative candidate) will become the active member we all expect him to be" they wrote, "there will no longer be a need for Clay as channel of communication with the government".

The Hull election of that year is in many ways reminiscent of $x 8$ th century elections with its emphasis on the commercial interests of the town and the extent to which personalities were the target of the electioneerings. It ended, perhaps significantly, in the unseating of Hoare following an election petition. Each of the two carpet bagging candidates promised favours to be received by the town after election. Hoare pointed out in his election address that "being connected with a mercantile community" he saw "the importance of relieving the shipping interest of all unnecessary burdens". He also declared that in his opinion there was a need for a bigger fleet but stressed at the same time the importance of doing away with waste at the Admiralty. Lewis on the other hand had been more down to earth in his concern for the welfare of the town he sought to represent: A director of the Galway-America Steamship Company, he had already placed orders for ships with Messrs. Samuelsons, prominent and strongly Liberal shipbuilders, and was looking forward to even closer associations with them in the future. No moral disapprobation was expressed at the clever wooing by the prospective candidate. The Packet and Conservative speakers only tried to prove that the association between Mr. Lewis and Messrs. Samuelsons had preceded his political connection with the borough, while the Liberals sought to vindicate their candidate against such slanderous attacks. ${ }^{1}$ Compared with such tangible proofs of affection Hoare could only promise to help with the building of a Park along the lines of London's Victoria Park.

Foreign Policy did not figure largely in the electoral discussion. Sir Charles Wood apart, no politician of national repute stood for any of the constituencies and no speeches aiming at a wide political audience were made. The discussion which the war between Austria and Italy had provoked on the national level was re-echoed rather than taken up in the Yorkshire cities. Public opinion, as it was reflected in the

1 The latter's 'vindication' is fairly convincing. It seems clear that Lewis' orders were the result of his well-founded hope to become a candidate for the borough and were placed after his informal adoption in the summer of 1858 . 
local Press, desired peace and expressed its concern. Britain was to remain neutral, everyone said, but she also ought to strengthen her defences. This view was expressed not only in Hull. Salt in Bradford desired a more efficient army and navy and others expressed similar sentiments. Here and there the Liberal candidates, in speeches or in reply to questions, showed their sympathy with the plight and aspirations of Italy. For Baines and Forster, campaigning in Leeds, both Austria and France were despotic powers and their conflict one in which Britain should not take part. However, beyond France's insincere advocacy there was the genuine problem of Italian independence. Her claims had their sympathy. Should Britain become involved in the conflict it was important that she be on the right side. For Clay and Forster than meant no alliance with Austria which sought to suppress Italy's freedom.

\section{THE CONDUCT OF THE ELECTION}

To learn how the elections were fought we have to turn to the accounts in the local Press and supplement this with material contained in the two election petitions which followed. ${ }^{1}$ The latter have to be used with care. They refer only to some aspects of the contests and are necessarily biased. On the other hand, they give details and local colour not to be found in Press reports. The Electioneering generally started soon after the government had announced its intention to dissolve Parliament. At the beginning of the second week of April the candidates began to move into position for the contest and by the end of that week meetings had started everywhere and canvassing was under way. Polling for all boroughs had been fixed for April 3oth. The election campaign usually began with the candidates addressing a respectful gathering from a window of the hotel which they had made their headquarters. It reached a crescendo of feverish activity in the week preceding polling week and gradually ebbed away during the last week to receive a final fillip and stimulus in the nomination meeting on the day before polling day. It is next to impossible to gauge today the extent to which election fever had touched the population. Judged solely by the tenor of the press and the record of the steady round of election meetings reported by the newspapers, we find little evidence of great enthusiasm nor, Huddersfield and Hull apart, of the fierce battle of party-warfare. Instead of speaking from the hustings the candidates made the round of the wards and of the townships surrounding the boroughs and partly included in the boundaries of the constituencies holding a series of short meetings.

1 BPP, 1859 , 2nd session, vols. III and IV. 
Thus in Leeds the two Liberal candidates addressed at least is meetings within 6 days. Starting off with an open air meeting on midday on Friday they held two meetings (at 7 o'clock and 8.30 in the evening). This pattern was repeated on Saturday and after a break for Sunday and "Saint" Monday throughout the following week. The meetings were usually held in Public Houses but sometimes also in Mechanics Institutes and in small halls. The candidates travelled with a retinue of their supporters and we can frequently notice the same names as chairmen or movers of resolution, suggesting lack of organisation at the Ward level. The meetings were quiet and the proceedings apparently decorous, ending generally with a unanimously passed resolution in favour of the candidate unless the opposing party had packed the meeting. ${ }^{1}$ This happened in the Bramley Ward of Leeds where at a Conservative meeting members of the audience called for a vote in favour of Baines and Forster and carried it by a large majority. The canvass went on all the while, undertaken partly by volunteers, partly by paid canvassers with occasional interventions by the candidate himself. Speaking shortly before the 1859 election and arguing the need for a secret ballot, John Bright gave the following description of canvassing procedure: "In calling on any particular elector the canvassers endeavour to find out his employer, his landlord, someone who has lent him money or done a kindness to some of his friends or who has some influence over him, and half a dozen meet together and though there may be nothing said, the elector knows very well there is somebody in that small number who has done him a benefit for which he expects a return, somebody who has power over him and who expects to be obeyed, and while the object is professedly that of a canvass it is little better than a demonstration of force and tyranny." " 2 So thorough an attempt at intimidation must, however, have been the exception rather than the rule. The smaller the community and the number of voters, the greater, of course, the opportunity for such pressure. The following letter, sent by the firm of solicitors who acted for the Conservative candidate in Hull, to solicitors in Barton (an out-township voting in Hull) carries such a flavour. "Dear Sir - Election. We send you two or three of Mr. Hoare's addresses and shall be obliged if you will immediately solicit such of your neighbours as are entitled to vote to use their influence on his behalf. We shall be happy to pay your charges..." signed: England \& Saxelbye, April 9th, $18590^{3}$ In general

${ }^{1}$ In Hull, we are told, a resolution in favour of Clay and Lewis was carried "in a most enthusiastic manner, a round of cheers being spiritually led by Mr. Wm. Lewis, the brother of the candidate".

2 Rogers, op. cit., vol. II, p. 65.

3 Hull Election Petition, loc. cit. 
it seems that canvassers, then as now, were pressed for time, especially as canvassing could effectively only be carried out during the evening when the men were at home. In Hull canvassing was done in pairs "a gentleman being paired with a paid man who knew the ward and knew the men". ${ }^{1}$ The purpose of the canvass was in the first place to ascertain the intention of the voter and thus to gain an impression of the strength of the parties. In Hull detailed instructions about canvassing procedure and the recording of the voters' intention were sent out by the central to the local committees. They contained the following passages:

"The canvassers are requested to record in their books the result of their call on each voter as recording 'promises' actually made, favourable or against but not to record as promises any but those distinctly made. They will also enter all removals, where possible, adding the new address and the names of those at sea or absent from Hull and ascertain if possible whether they are likely to return for the election... The chairman of each committee will be furnished with a ledger containing an alphabetical list of voters in his district in which the result of the canvass should each day be carefully entered from the canvass books. He will also be furnished with forms on which a return should be made each evening to the Central Committee on the result of the day's canvass." 2

To what further extent they went, tried to persuade and possibly use other means varied obviously a great deal from place to place. In Huddersfield some canvassers were certainly not squeamish. "Notes of Elegance" were flashed and money was jingled (the actual bribing, however, was done by less obvious means). The story of a single canvass is illustrative:

"Q. After that took place did Burton ask you about voting for anyone?

A. Burton said 'You are going to vote for Ackroyd, are you not' and I said 'Yes'.

Q. Was anything more said about voting?

A. He said 'I thought you would have been a man for our side and for the working classes'. I said, 'I was for the working men's side, but I should vote for Mr. Ackroyd'.

Q. Did he make any remark about that?

A. He then produced Mr. Leatham's address and showed me that he was for an extension of the suffrage and for the ballot

1 Ibid. 6066.

2 Ibid. 4544 . 
and he thought it would be a good deal better for me if I voted for him.

Q. What did you say upon that?

A. I said I should not go for Mr. Leatham, my intentions were for Mr. Ackroyd.

Q. When that had been said and done what was further done by Burton?

A. After some further conversation about the address we advanced more into the interior of the room ... and he gently placed his hand on my right shoulder and then privately whispered into my ear... and asked me if a $£$ s note would be of any use to me. I said 'No' and he then said 'come now, let us see if it would.' I said 'No, it would not, but if in case anything was to come in as regards that, it would unseat Mr. Leatham and that would be doing wrong'. He said 'Don't think anything about that, for this is a thing that is done regularly in elections' ... He then pressed on me again but I told him I would not take one halfpenny to any sum he could mention." 1

Apart from meetings and canvassing our knowledge of electioneering methods is not very extensive. In Hull poll cards were distributed, and hoardings and houses were covered with posters, but they probably carried little more than the name of the candidate with some simple slogans such as "Leatham the man for the people". ${ }^{2}$ In Huddersfield posters also annnounced the location of "Non-Electors Committee Rooms" which in that town were very numerous. While those in Huddersfield fulfilled a function in attempts at bribery and corruption we can neither there nor elsewhere explain the electoral activity of non-electors even primarily in terms of illegal election practices. ${ }^{3} \mathrm{We}$ must regard the intervention of the non-electors, especially where it was obviousbly fostered by sections of the Liberal leadership in the constituencies, as an attempt to influence the body of voters in favour of reform candidates and reform measures. The political aspirations of the Middle Class had been largely fulfilled by the 1832 Act and by the Reform measures which followed it; to induce it to rank itself behind further (and, as many thought, revolutionary) electoral reforms it

1 Huddersfield Eelection Petition, roc. cit.

${ }^{2}$ In Hull posters directed against Lewis were strongly derogatory in character. The Conservative Chairman disclaimed all knowledge of them. They disappeared soon afterwards.

${ }^{3}$ Bribery was possible through the payment of landlords for the letting of non-electors Committee rooms or for allowing their walls to be covered with posters. 
needed considerable outside pressure. Cobden recognised this problem clearly. In a letter written towards the end of 1858 to a correspondent who had suggested more extensive franchise reforms than those advocated by Bright, he expressed his doubt whether the latter's proposals could be realised. A "multitudinous demonstration by the unenfranchised in favour of parliamentary reform" was needed. "But I am afraid "he went on "you (i.e. Lancashire) are too prosperous and the people too well fed to warrant the hope that Lancashire will come to the rescue. Until the masses do again put in their claim for the franchise they will not obtain it. It is not in human nature that the middle class, who are already within the privileged pale should be eager to admit those outside to share their power unless they are gently pressed to open the door." " 1 Some such pressure was certainly applied during the 1859 contest but it is, at the same time, obvious, that it was not sufficient, and quite possibly could not be sufficient, to create a vigorous public clamour for far-reaching reforms. The activities of the Halifax Household-Suffrage and Ballot Association which had existed well before the election and had been instrumental in the selection of a radical as a second candidate as well as a meeting of working men held in Hull at the opening of the contest to form a similar association belongs more strictly speaking to the pre-election agitation and must be put in context with the widespread agitation carried out by the Northern Reform Union in the winter of 1858 -59. The Halifax Association, however, was probably responsible for the convening of a meeting of 1,000 non-electors held in the Market Place towards the end of the election campaign. While the raison d'être of the meeting - the support of the Liberal candidates - had been destroyed by the withdrawal of their Conservative opponent, the meeting gave expression to the sentiment that the non-electors regarded Stansfield as their candidate. "If he had not been in the field the non-electors would have taken little interest in the election" declared the chairman.

Similar meetings were held in Bradford, Leeds, Huddersfield and York, either jointly for the whole town or separately for the wards. The meetings held in Leeds passed two resolutions. The first proclaimed Baines and Forster to be "the two candidates most likely to secure for us the greatest possible extension of the suffrage" and promised to assist the electors to secure the return of these candidates. In the second, non-electors pledged themselves to be present at nomination to gain

1 Quoted in Robertson, Life of Bright, 1883 ed., p. 264. On Working Class apathy see also John Saville (ed.), Emest Jones, Chartist, p. 74 . 
the show of hands for their candidates. ${ }^{1}$ The attitude of some Bradford non-electors was less practical but it made up for it by an excess of sentiment and rhetoric, showing chartist concepts still at work.

"If ever there was a time... when the intelligence, union and energy of the working classes should be brought to bear politically, now is the time"

it began, and then urged non-electors to be active in favour of Titus Salt.

"Your decision is all powerful, your voice is paramount. The voice of the people is the voice of God... Urge upon the electors the justice and the necessity of voting for Salt... Tell them, by voting for Harris they politically ignore us as a class, thereby declaring themselves to be our worst and bitterest enemies... Tell them furthermore that the great moral law of brotherhood... calls aloud upon them to vote for such men as are pledged to give us our political rights, for are we not men and brothers?" 2

The extent to which non-electors could influence voters depended above all on the social composition of the electorate and the existence of social and family ties between the two groups. There were probably few such ties in Leeds with its prevalence of low-rent working class homes, a consequently small electorate and an even smaller group of working-class voters, while in Huddersfield, where one householder in four was enfranchised the "bargaining position" of the non-elector was undoubtedly stronger. ${ }^{3}$ A strong freemen electorate was open to similar influences. At a meeting of non-electors connected with the North-Eastern Railway works in York, the audience was urged to exert their influence on their fathers, uncles and brothers who had the vote. The organisation of the non-elector has two related functions. It mobilizes an aggrieved section of the population and it makes their demands articulate. As a body it presents itself to the enfranchised middle class and tries to touch chords of sympathy, of latent radical sentiments as well as considerations of prudence. Individually each of

1 Although of no political significance, the show of hands was of some psychological importance as its outcome might influence wavering voters. In Leeds the Mercury remonstrated with the Mayor who, as returning officer, had given the show of hands to Baines and Beecroft. The paper thought that it should have gone to Baines and Forster as all the hands that went up for the former had also gone up for the latter.

2 From the "Address of the Non-Electors of the Little Horton Ward to the Electors of the Borough of Bradford".

3 There was, of course, the pressure on Shopkeepers and publicans which non-electors as well as voters could exercise. While this could be purely social it could also be outright intimidation. Cf. Huddersfield Election Petition, loc. cit., I5 5-246. 
the unenfranchised will feel fortified by the expression of group solidarity and will more readily argue with his enfranchised neighbour and press his claim.

\section{VOTERS AND VOTING}

Polling was heavy. In Huddersfield I 449 votes were cast out of an electorate of 1686 and even in Hull the percentage of voters was $75 .^{1}$ Such high figures would be surprising if they were not consistent with the voting records of the constituencies throughout the period between the first and the second Reform Act. If we can detect any movement in the volume of electoral participation at all it is in the 1837 and 1841 elections where the figures were generally a little lower than in the preceding and the following elections. ${ }^{2}$ The voting figures reveal the political inclinations of the electorate. Conservative voters were encouraged and expected to plump for their candidate yet none of the three victorious Conservative candidates succeeded on the plumpers' vote only; they were all assisted by voters who split between them and the moderate of the two Liberal candidates. Splitting between the Conservative and the Radical candidate, on the other hand, was negligeable, exceeding nowhere $3 \%$ of all votes cast. On the other end of the scale we find, with the exception of Bradford, only a handful of voters who plumped for the Radical candidate. ${ }^{3}$

The returns of the four constituencies where three candidates contested two seats, presented below, show different patterns of the alignment of political forces. Behind the label "Whig or Moderate Liberal" stand, of course, candidates of fairly different persuasions, not always clearly distinguishable from their radical colleague or their conservative opponent. Thus in Bradford H. W. Wickham, now supported by Liberal votes, had been the Conservative representative of the town in the previous Parliament while Clay in Hull held fairly advanced views. The cross-voting so marked in the two towns, reflects either the attachment of the Conservative elements to their old representative or

\footnotetext{
1 These percentages do not allow for duplicate entries on the register. In Bradford it was thought that the 3,600 entries on the register represented 3,300 electors. On that basis the percentage of the electorate voting is 90.

2 Cf. W. Bean, The parliamentary representation of the six Northern Counties of England, where the figures of the electorates and of the number voting are given. Bean's figures seem based on actual analyses of polls and not deduced from voting figures. They were tested for the 1859 election and were found to be correct.

3 In Leeds 104 voters plumped for Forster but only 66 for Baines. In Bradford Salt's committee attempted at first to secure a large number of plumpers in order to ensure his return at the head of the poll. A last minute fear that this might lead to a victory of Wickham and the conservative candidate made them change their tactics, thereby defeating Harris but, at the same time, putting Wickham at the head of the poll.
} 
the unwillingness of moderate Liberals to let in a man of radical views and possibly a carpet-bagger to boot.

PERCENTAGE DISTRIBUTION OF VOTERS

\begin{tabular}{|c|c|c|c|c|c|c|c|}
\hline \multirow[t]{2}{*}{ CONSTITUENCY. } & \multicolumn{3}{|c|}{ PLUMPERS } & \multicolumn{3}{|c|}{ SPLITS } & \multirow[t]{2}{*}{ TOTAL } \\
\hline & Cons. & $\begin{array}{l}\text { Wbig or } \\
\text { Mod. Liberal }\end{array}$ & Rad. & $\begin{array}{l}\text { Cons. } \\
\text { Wbig. }\end{array}$ & $\begin{array}{l}\text { Cons. } \\
\text { Rad. }\end{array}$ & $\begin{array}{l}\text { Whig } \\
\text { Rad. }\end{array}$ & \\
\hline Bradford & 19 & 3 & 9 & 20 & 3 & 46 & 2,967 \\
\hline Hull & $3^{8}$ & 0.8 & 0.6 & 14 & 3 & 44 & 4,145 \\
\hline Leeds & 44 & I & 2 & 5 & 2 & 46 & $4,53^{8}$ \\
\hline York & 45 & 0.5 & 0.5 & 6 & I & 47 & $3,49^{\circ}$ \\
\hline
\end{tabular}

Unless the votes recorded are due to error or confusion each of the six forms of voting-behaviour will represent slightly different attitudes (whether they are the result of rational considerations or due to pressure or persuasion we cannot know) and their further analysis on the basis of poll-books showing the voting for wards or districts permit more detailed investigation. ${ }^{1}$ The figures for Bradford show only little difference in the distribution of votes between the borough and each and all of the out-townships; if anything they are slightly more radical. I $1 \%$ of their voters plumped for Titus Salt compared with $8 \%$ in the borough. A similar division in Leeds, on the other hand, shows a higher percentage of conservative plumpers in the outtownships than in the borough ( $46 \%$ against $42 \%$ ).

In the two richest wards of Leeds, with $73 \%$ and $64 \%$ of all houses having a rental of $£$ io and over we find that the radical candidate polled 349 votes compared with the Conservative's 360 . Yet in the two poorest wards, with only $8 \%$ of all houses having that rental, conservative votes exceed radical votes by $6 \%$. In the four remaining wards, occupying an intermediary position, radical votes are decidedly greater than conservative, i.e., 876 against 778 . The figures only hint at the possibility that both the upper as well as the lowest section of the Middle Class may be more inclined to vote conservative than its middle sections. In York we find that in the booths where the electors of Clifton, a fashionable part of the town, voted, the conservative candidate received twice the number of votes of his radical opponent and in the booths registering the votes of the electors of Minster Yard the discrepancy was nearly as great. In other parts however (Parishes

1 Such figures were found for Leeds and the Bradford Poll Book which distinguishes unfortunately only between the borough and the three out-townships was analysed by the author. Where the poll books give addresses of voters and where the relevant Census schedules are available a more detailed study of voting behaviour could be undertaken. In the case of the election here studied both pre-requisites were absent. 
of St. Nicholas, St. Peter le Willows, St. Lawrence and St. George as well as in St. Mary Bishopshill Junior) the Liberal Voters exceeded Conservatives by over $60 \%$.

In Huddersfield where two Liberal candidates opposed each other in a straight fight, we have more detailed information of the character and composition of the two opposing groups. The men who supported the victorious candidate belonged obviously to the socially less prosperous sections of the electorate. ${ }^{1}$ The moderate of the two Liberal papers claimed that the leading notables of the town "together with the entire clergy and a number of ministers" as well as "the major portion of reputable shopkeepers and tradesmen" voted for the defeated candidate and a correspondent to that paper describes Leatham as the elect of a faction whose relative social position is but ten to one when compared with the supporters of Mr. Ackroyd. "Let the poor-rate be analysed, let the government tax be scrutinized and the result will show that Mr. Ackroyd's supporters contributed more than ten-fold the amount paid by their opponents". Religious as well as social divisions manifest themselves among the Huddersfield electorate. Ackroyd ascribed his defeat partly to the "union between sectarianism and democracy" and a non-conformist minister, when charged by the Huddersfield Chronicle with using his influence among his congregation in favour of Leatham replies by admitting that he did so in one or two cases but adds that the great majority of those under his charge needed no persuasion.

\section{CONCLUSIONS}

In this paper an attempt has been made to describe a mid-Victorian election campaign in what can be regarded as a representative group of city electorates of industrial England and to analyse it in terms of some of the social and political forces at work in the constituencies. For this reason I have sought to relate the body of voters to the structure of the whole population of the towns. For similar reasons I have tried to investigate the social composition of the body of candidates and their relationship to various sections of the communities studied. This demanded the study of the issues raised during the contest, the investigation of some local issues and pressure group activities and finally the analysis of voting figures.

The evaluating and quantitative study of political behaviour is a difficult enterprise even with the use of modern sociological methods

1 A list of Leatham's workers (i.e., those who followed his carriage after the declaration of the poll contains among 23 names only 2 J.P.'s and 3 men to whom the paper gives the title 'esq.' (including the two justices). 
such as sample surveys and prolonged and repeated interviews, and the findings are often more suggestive than conclusive. The study of politics at a distance can obviously bring even less certainty. Even the existence of voting records giving the political decisions of individuals and the lengthy treatment of election meetings in the local press (much fuller than today) cannot compensate for the impossibility to interview voters and candidates. Here the absence of any records of local political organizations which might have given "behind the scenes" information is especially to be regretted. The results show clearly the limitations but I hope also some of the possibilities of studies of this kind.

Within the wider framework I have tried to focus attention on the political behaviour of the working class, enfranchised or unenfranchised. The I $850^{\circ}$ ies are generally regarded as a period when the working class was in the political doldrums, exhausted after the defeat of chartism. ${ }^{1}$ Yet "the populous districts were never completely quiet in the mid-Victorian period even when they appeared to be quiescent". ${ }^{2}$ Chartism as an organized force had indeed largely disappeared from the political scenes of the Yorkshire constituencies. In Leeds an attempt was made to put forward a Mr. James Shaw as a chartist candidate but at the nomination meeting his supporters were refused a hearing by the crowd and he withdrew. This incident and chartist phrases re-echoed in the reform meetings are the only traces of the movement we can detect. ${ }^{3}$ But the universal manifestation of "Household Franchise \& Ballot Associations", non-electors committees and other predominantly working-class organizations tell on the local level a table of some vigorous political activity by artisans and labourers. What is more, there is clear evidence of strong and vocal participation of working men in the meetings urging electoral reforms which preceded and followed the government bill. Their presence on the platform of such meetings presents a comparatively novel feature and was regarded by one working class speaker as an indication of the political emancipation of his class.

The pattern of this activity follows the example set by the Northern Reform Union with its large working class membership and a leader-

1 But see: F. E. Gillespie, Labour and Politics in England, 1850-67.

2 Asa Briggs, Victorian People, p. 239.

3 The position in Halifax is illustrated by a letter of John Snowden to Ernest Jones in reply to the latter's appeal for funds. "There is no Chartist organization in Halifax nor in any of the villages surrounding it... many have emigrated. Others... have become so thoroughly disgusted at the indifference of the multitude to their best interest that they are resolved to make no more sacrifices in a public cause..."

Quoted by Saville, Ernest Jones, Chartist, p. 74. 
ship recruited from both middle and working class. The Union sought to extend its influence over a wider area than Tyneside where it started, and there is some evidence that its contacts extended to Yorkshire. ${ }^{1}$ Reference to its petitioning activities in the North were made in the Yorkshire press and 1t may well have helped to instigate the series of franchise reform petitions some mention of which was made above. The Parliamentary Reform Association, too, made propaganda in the provinces. Most of the Liberal papers studied carried a letter "addressed to friends of reform throughout the kingdom" in which he urges the selection of progressive Liberal candidates and the general support for John Bright's proposals. "The committee" the letter concluded "will gladly render any assistance to you in their power".

On the Liberal side the local elections must clearly be put in the context of a wider movement. To do this here would have meant the study of the activities of organizations, such as those mentioned, hitherto largely uninvestigated. I could therefore only hint at these connections.

Although the result of the elections on the national level was indecisive and the reform agitation which it aroused brought no fruit in terms of political action, it served, at least in the Yorkshire cities, as a rallying point for radical forces. It is thus a prologue to the electoral reform movement of the mid-1 860'ies and the I 867 Reform Act. ${ }^{2}$

1 I am much indebted to Mr. C. Muris for the loan of his thesis on the Northern Reform Union (The Northern Reform Union, 18 8 8-1862, M. A. thesis, Dept. of Education, King's College, University of Durham).

2 The author is greatly indebted to Sir Lewis Namier and Professor Asa Briggs for their comments on a draft of this paper. 